\title{
Effect of Different Levels of Irrigation and Nutrient Management Practices on the Performance of Tomato (Lycopersicon esculentum L.)
}

\author{
A. K. Dash ${ }^{1}$, B. R. Nayak ${ }^{2 *}$ and N. Panigrahy ${ }^{3}$
}

All India Coordinated Research Project on Water Management, Regional Research \& Technology Transfer Station, OUAT,Chiplima, Sambalpur, Odisha (768 025), India

\section{Article History}

Manuscript No. AR845

Received in $12^{\text {th }}$ July, 2014

Received in revised form $12^{\text {th }}$ November, 2014

Accepted in final form $5^{\text {th }}$ January, 2015

\section{Correspondence to}

*E-mail: biswa.nayak@yahoo.co.in

\section{Keywords}

Tomato, yield, farmyard manure, water use efficiency, economics

\begin{abstract}
To study the effect of different levels of irrigation and nutrient management practices on yield and water use efficiency of tomato (cv. Utkal Kumari) a field experiment, with three irrigation schedules and four nutrient management practices, was conducted in the Regional Research Technology and Transfer Station (RRTTS), Chiplima, Sambalpur for three years. Three years pooled mean of tomato fruit yield indicated that highest fruit yield of $18.48 \mathrm{tha}^{-1}$ was observed with IW:CPE of 1.2 irrespective of different nutrient management practices. Highest pooled mean fruit yield of $19.07 \mathrm{t}$ $\mathrm{ha}^{-1}$ was recorded with application of $25 \%$ organic $+75 \%$ inorganic which was significantly superior to $50 \%$ organic $+50 \%$ inorganic $\left(18.26 \mathrm{t} \mathrm{ha}^{-1}\right), 100 \%$ organic $(16.01$ $\left.\mathrm{t} \mathrm{ha}^{-1}\right)$ and $100 \%$ inorganic $\left(17.21 \mathrm{t} \mathrm{ha}^{-1}\right)$ irrespective of different irrigation levels. Highest mean water use efficiencies of $533.45 \mathrm{~kg} \mathrm{ha}^{-1} \mathrm{~cm}^{-1}$ and $469.47 \mathrm{~kg} \mathrm{ha}^{-1} \mathrm{~cm}^{-1}$ were observed with IW:CPE of 0.8 and application of $25 \%$ organic $+75 \%$ inorganic fertilizer respectively. Among the irrigation treatments highest net return (₹ 56,136/-) and benefit-cost ratio (2.03) were observed with 1.2 IW:CPE, whereas the highest net return (₹ 61,560/-) and benefit-cost ratio (2.16) were observed with $25 \%$ organic $+75 \%$ inorganic fertilzer. Thus, integrated use of $25 \%$ organic along with $75 \%$ inorganic fertilizer as per recommended dose of nutrient with an irrigation scheduling at 1.2 IW:CPE produced highest fruit yield of tomato as compared to other treatments. The fruit yield per hectare was significantly correlated to all other yield attributing parameters except days to first harvest.
\end{abstract}

\section{Introduction}

Tomato (Lycopersicon esculentum Mill) is one of the most popular vegetable crop grown in almost all parts of India due to its wider adaptability to various agro climatic conditions. It is one of the most important vegetable crops of India as well as Odisha in respects to its production and cultivated area. Application of required dose of fertilizer and water increase the yield and quality of tomato. Improper irrigation management practices not only waste scarce and expensive water resources but also decrease crop yield (Tiwari et al., 1998). Similarly fertilizers played a key role in increasing crop productivity and quality. The practice of indiscriminate and continious use of inorganic fertilizers affected the soil health and soil microbial activity. Thus, application of farmyard manure (FYM) increased the total microbial population in the soil (Senapati et al., 2011). The integrated nutrient use of organic and inorganic fertilizers has assumed great significance in recent years. Vermicompost is a stable organic manure, which can be applied alone or in combination with organic and inorganic fertilizer for better yield and quality product of different crops (Arancon et al., 2006 and Jack et al., 2011). Being a heavy feeder it can removed $80 \mathrm{~kg}$ nitrogen, 20 $\mathrm{kg}$ phosphorus and $130 \mathrm{~kg}$ potassium for 37 tonnes of fruit production (Premnath et al., 2008). Tomato is an exhaustive crop which responded well to higher amount of organic and inorganic fertilizers. The integrated use of biofertilizers and recommended dose of fertilizers had positive effect on stability and sustainability of crop production of tomato (Chaurasia et al., 2001) and Gajbhiye et al., 2003). Information relating to interaction effect of organic as well as inorganic fertilizer along with irrigation levels are scarce on tomato .Therefore, an experiment was conducted to study the effect of irrigation along with both organic and inorganic fertilizers on yield and water use efficiency in tomato. 


\section{Materials and Methods}

An experiment was conducted at the Regional Research Technology and Transfer Station (RRTTS), Chiplima, Sambalpur in the year 2009, 2010 and 2011 during the rabi season. The latitude, longitude and altitude of the study area are $20^{\circ} 21^{\prime} \mathrm{N}, 80^{\circ} 55^{\prime} \mathrm{E}$ and $178.8 \mathrm{~m}$ above mean sea level, respectively. The soil of the experimental field was sandy loam with acidic in reaction ( $\mathrm{pH} 5.5$ ), organic carbon content was $0.43 \%$ and available N, P and K content was $227,11.0$ and 158 $\mathrm{kg} \mathrm{ha}^{-1}$, respectively. The percentage of nitrogen, phosphorus and potassium of FYM $(0.53,0.30$ and 0.63$)$, neem cake $(4.8,1.0$ and 1.5) and vermicompost (1.2,0.4 and 0.6), respectively. The moisture content at field capacity and permanent wilting point was 19.4 and $8.4 \%$, respectively. Sixteen treatments comprised of four irrigation levels (IW: $\mathrm{CPE}=0.8 ; \mathrm{IW}: \mathrm{CPE}=1.0$; IW:CPE $=1.2 ; \mathrm{IW}: \mathrm{CPE}=1.4)$ as the main plots and four levels of nutrients $\left(\mathrm{N}_{1}: 100 \%\right.$ organic (FYM $12.5 \mathrm{t} \mathrm{ha}^{-1}+$ Vermicompost $2.5 \mathrm{t} \mathrm{ha}^{-1}+$ Neem cake $\left.500 \mathrm{~kg} \mathrm{ha}^{-1}\right) ; \mathrm{N}_{2}: 100 \%$ inorganic (RD$120: 50: 100$ of $\left.\mathrm{N}: \mathrm{P}_{2} \mathrm{O}_{5}: \mathrm{K}_{2} \mathrm{O}\right) ; \mathrm{N}_{3}: 25 \%$ organic $+75 \%$ inorganic; $\mathrm{N}_{4}: 50 \%$ organic $+50 \%$ inorganic as sub-plots in split plot design with four replications. The irrigation water of $5 \mathrm{~cm}$ was applied when cumulative pan evaporation reached $62.5,50,41.6$ and $35.7 \mathrm{~mm}$ for IW:CPE of $0.8,1.0,1.2$ and 1.4, respectively. The total rainfall during the crop growth period were 7.2 $\mathrm{mm}, 27.8 \mathrm{~mm}$ and $65.5 \mathrm{~mm}$ received in 1,3 and 9 rainy days during 2009, 2010 and 2011 respectively. Tomato cv. BT-10 (Utkal kumari) was treated with vitavax $\left(2 \mathrm{~g} \mathrm{~kg}^{-1}\right.$ seed) sown in nursery on $1^{\text {st }}$ week of November. and twenty eight days old healthy seedling were transplanted in the main field at a spacing of $60 \times 45 \mathrm{~cm}^{2}$ in each year. The FYM was applied at the time of land preparation where as full dose of phosphorus and potassium along with half dose of nitrogen were applied at the time of transplanting as per treatment plan. Rest nitrogen was top dressed after fourty days of transplanting. Recommended cultural practices were followed during experiment. At the initial stage of crop, first two light common irrigation were applied for proper establishment of the plants. The volume of irrigation water in each plot was calculated by multiplying the depth of irrigation and area of the plot. Irrigations were given as per treatments when CPE reached at required level and measured quantity of irrigation water was applied with the help of $90^{\circ} \mathrm{V}$-notch. Ten plants were selected randomly from each net plot area for taking observations on growth and yield components. Fruit yield was calculated on the net plot basis. Water requirement (WR) was calculated by adding effective rainfall during crop growth period, amount of irrigation water applied and soil profile contribution. Water use efficiency (WUE) was calculated by dividing fruit yield $\left(\mathrm{kg} \mathrm{ha}^{-1}\right)$ with the total water requirement $(\mathrm{cm})$ of the crop. Economics for different treatment was calculated on the basis of prevailing market price of the produce and inputs used in the experiment. The recorded data for various parameters were statistically analyzed (Panse and Sukhatme, 1978).

\section{Results and Discussion}

\subsection{Yield attributing arameters}

Effect of irrigation scheduling irrespective of nutrient management on yield attributing parameters of tomato was presented in Table 1. Maximum plant height $(43.28 \mathrm{~cm})$ and days to first harvest (74.58 days)were recorded with IW:CPE of 1.4, which was at par with IW:CPE of 1.2. But it was significantly superior to that of other irrigation levels. Maximum number of branches plant ${ }^{-1}$ (12.17) was recorded with IW:CPE of 1.4, which was at par with that observed with IW:CPE of 1.2 and 1.0 but significantly superior to the value observed with IW:CPE of 0.8 irrigation levels. Maximum leaves plant ${ }^{-1}(67.25)$, retention of fruit plant ${ }^{-1}$ (24.83), average fruit weight (37.83) and fruit yield plant ${ }^{-1}(0.981 \mathrm{~kg})$ were recorded with IW:CPE of 1.2, which was significantly superior to all other irrigation levels.

Effect of nutrient management on the yield attributing parameters of tomato for three years irrespective of irrigation levels was presented in Table 1. The poled mean of all three years showed that the yield attributing parameters were positively influenced by the nutrient management practices (Table 1). Application of $25 \%$ organic $+75 \%$ inorganic fertilizer was recorded maximum plant height $(43.35 \mathrm{~cm})$ and leaves plant $^{-1}(65.10)$ which was significantly superior to $100 \%$ organic and $100 \%$ inorganic applied plot. But it was statistically at par with the fruit yield due to application of $50 \%$ organic $+50 \%$ inorganic. The maximum number of branches plant $^{-1}$, average weight of fruit and fruit yield plant ${ }^{-1}(0.862$ $\mathrm{kg}$ ) were recorded due to the application of $25 \%$ organic $+75 \%$ inorganic which was significantly superior to that of $100 \%$ organic only but the value was at par with $50 \%$ organic $+50 \%$ inorganic as well as 100\% inorganic fertilizer. Highest fruit retention plant ${ }^{-1}$ was recorded due to the application of $25 \%$ organic $+75 \%$ inorganic which was significantly superior to all other nutrient management practices, wheras maximum days required to first harvest was observed with $100 \%$ inorganic fertilizer which was significantly superior to all other nutrient management practices,

\subsection{Fruit yield}

The pooled mean fruit yield of tomato in all three years (Table 1) was statistically significant due to imposition of different irrigation treatments. The pooled mean value indicated that, highest fruit yield was obtained at IW:CPE of $1.2\left(18.48 \mathrm{tha}^{-1}\right)$ which was significantly superior to IW:CPE of $1.4\left(17.50 \mathrm{tha}^{-1}\right)$ ,IW:CPE of $1.0\left(17.38 \mathrm{tha}^{-1}\right)$ and IW:CPE of $0.8\left(17.20 \mathrm{tha}^{-1}\right)$. The irrigation scheduled at IW:CPE of $1.4,1.0$ and 0.8 were 
not differed significantly from each other. The crop receiving of irrigation scheduled at IW:CPE of 1.2 increased the grain yield over IW:CPE of 1.4, IW:CPE of 1.0 and IW:CPE of 0.8 by $5.60,6.33$ and $7.44 \%$,respectively. The better performance of tomato crop under IW:CPE of 1.2 might be due to the favorable soil water environment in the rhizosphere, which indirectly helped the plants for efficient utilization of water as well as nutrients. This result confirms the result of Chatterjee and Mallick (2008). They reported that wetter moisture regimes (IW:CPE of 1.2) increased the fruit yield of tomato by 12.39 and $26.89 \%$ over drier moisture regimes at IW:CPE of 1.0 and IW:CPE of 0.8 , respectively.

The pooled mean fruit yield of tomato for all three years indicated was statistically significant due to imposition of nutrient management practices. The maximum fruit yield of $19.07 \mathrm{t} \mathrm{ha}^{-1}$ was obtained due to the application of $25 \%$ organic $+75 \%$ inorganic, but it was significantly superior to that of $50 \%$ organic $+50 \%$ inorganic $\left(18.26 \mathrm{t} \mathrm{ha}^{-1}\right), 100 \%$ inorganic $\left(17.21 \mathrm{t} \mathrm{ha}^{-1}\right)$ and $100 \%$ organic $\left(16.01 \mathrm{t} \mathrm{ha}^{-1}\right)$. All the nutrient management practices differed significantly from each other. The increase in grain yield owing to application of $25 \%$ organic $+75 \%$ inorganic over $50 \%$ organic $+50 \%$ inorganic, $100 \%$ inorganic and $100 \%$ organic were 4.43 , 10.80 and $19.05 \%$, respectively. This confirms the significance of conjunctive use of organic and inorganic fertilizers than that of individual one. This effect might be due to more availability of different plant nutrients because of the activity of microorganisms present in FYM. This result corroborates the findings of Kumaran et al. (1998) where they observed higher fruit yield of tomato by the application of NPK with FYM and vermin compost. Bahadur et al. (2004) also reported that application of organic manures combined with recommended dose of inorganic fertilizers showed superior performance in tomato. Kumar and Sharma (2004) reported that application of organic manures with NPK were found best in obtaining higher values for yield and available macronutrients (NPK) in both tomato (Lycopersicon esculentum) and carrot. Chatterjee and Bandhyopadhyay (2014) reported that application of four tonnes vermicompost per hectare supplemented with $75 \%$ recommended inorganic fertilizer inoculated with Azophos resulted maximum uptake of macronutrients and subsequently helped for achieving higher yield of tomato with sustainable soil health.The interaction effect of both irrigation schedules and nutrient management practices on fruit yield from the three years pooled mean was not statistically significant. However, irrigation schedule at IW:CPE of 1.2 and nutrient management of $25 \%$ organic $+75 \%$ inorganic produced highest fruit yield among different interaction.

\subsection{Seed yield and its attributes}

Effect of irrigation scheduling irrespective of nutrient management on seed yield attributing parameters as well as

\begin{tabular}{|c|c|c|c|c|c|c|c|c|c|c|c|c|}
\hline Treatments & $\begin{array}{l}\text { Plant } \\
\text { height } \\
(\mathrm{cm})\end{array}$ & $\begin{array}{l}\text { Branch- } \\
\text { es } \\
\text { plant }^{-1}\end{array}$ & $\begin{array}{l}\text { Leaves } \\
\text { plant }^{-1}\end{array}$ & $\begin{array}{c}\text { Days } \\
\text { to first } \\
\text { har- } \\
\text { vest } \\
\text { (days) }\end{array}$ & $\begin{array}{l}\text { Fruit } \\
\text { reten- } \\
\text { tion } \\
\text { plant }^{-1}\end{array}$ & $\begin{array}{l}\text { Aver- } \\
\text { age } \\
\text { fruit } \\
\text { weight } \\
(\mathrm{g})\end{array}$ & $\begin{array}{c}\text { Fruit } \\
\text { yield } \\
\text { plant }^{-1} \\
(\mathrm{~kg})\end{array}$ & $\begin{array}{c}\text { Fruit } \\
\text { Yield } \\
\left(\mathrm{t} \mathrm{ha}^{-1}\right)\end{array}$ & $\begin{array}{c}\text { Seed } \\
\text { recov- } \\
\text { ery } \\
(\%)\end{array}$ & $\begin{array}{c}100 \\
\text { seed } \\
\text { weight } \\
(\mathrm{g})\end{array}$ & $\begin{array}{c}\text { Seed } \\
\text { yield } \\
\text { plant }^{-1} \\
(\mathrm{~g})\end{array}$ & $\begin{array}{c}\text { Seed } \\
\text { yield } \\
\left(\mathrm{kg} \mathrm{ha}^{-1}\right)\end{array}$ \\
\hline \multicolumn{13}{|c|}{ Effect of irrigation schedules } \\
\hline IW:CPE $=0.8$ & 35.65 & 9.33 & 58.45 & 71.66 & 17.33 & 32.41 & 0.586 & 17.20 & 0.41 & 0.272 & 2.40 & 70.00 \\
\hline $\mathrm{IW}: \mathrm{CPE}=1.0$ & 40.18 & 11.58 & 61.85 & 73.08 & 21.00 & 34.4 & 0.707 & 17.38 & 0.43 & 0.291 & 3.04 & 73.78 \\
\hline $\mathrm{IW}: \mathrm{CPE}=1.2$ & 43.08 & 12.08 & 67.25 & 73.25 & 24.83 & 37.83 & 0.918 & 18.48 & 0.47 & 0.330 & 4.33 & 83.70 \\
\hline IW:CPE $=1.4$ & 43.28 & 12.17 & 63.79 & 74.58 & 22.67 & 35.33 & 0.807 & 17.50 & 0.45 & 0.313 & 3.61 & 80.90 \\
\hline $\mathrm{SEm} \pm$ & 0.87 & 0.39 & 0.71 & 0.40 & 0.59 & 0.64 & 0.020 & 0.21 & 0.005 & 0.007 & 0.11 & 2.29 \\
\hline $\mathrm{CD}(p=0.05)$ & 3.02 & 1.34 & 2.28 & 1.41 & 2.04 & 2.20 & 0.063 & 0.62 & 0.02 & 0.023 & 0.34 & 7.32 \\
\hline \multicolumn{13}{|c|}{ Effect of nutrient management } \\
\hline $\mathrm{N}_{1}: 100 \%$ organic & 36.83 & 9.41 & 59.88 & 70.50 & 19.08 & 31.85 & 0.653 & 16.01 & 0.42 & 0.286 & 2.75 & 65.00 \\
\hline $\mathrm{N}_{2}: 100 \%$ inorganic & 40.18 & 11.50 & 62.71 & 75.25 & 21.04 & 35.16 & 0.743 & 17.21 & 0.43 & 0.299 & 3.30 & 75.47 \\
\hline $\begin{array}{l}\mathrm{N}_{3}: 25 \% \text { organic }+ \\
75 \% \text { inorganic }\end{array}$ & 43.35 & 12.50 & 65.10 & 73.75 & 24.60 & 37.41 & 0.862 & 19.07 & 0.46 & 0.314 & 3.96 & 87.34 \\
\hline $\begin{array}{l}\mathrm{N}_{4}: 50 \% \text { organic }+ \\
50 \% \text { inorganic }\end{array}$ & 41.85 & 11.75 & 63.65 & 72.83 & 21.08 & 35.56 & 0.761 & 18.26 & 0.45 & 0.305 & 3.43 & 80.66 \\
\hline $\mathrm{SEm} \pm$ & 0.90 & 0.40 & 1.00 & 0.31 & 0.81 & 1.12 & 0.016 & 0.14 & 0.007 & 0.006 & 0.09 & 2.03 \\
\hline $\mathrm{CD}(p=0.05)$ & 2.63 & 1.18 & 2.89 & 0.91 & 2.37 & 3.29 & 0.045 & 0.38 & 0.02 & 0.016 & 0.25 & 5.83 \\
\hline
\end{tabular}


seed yield of tomato were presented in Table 1. Irrigation regimes with IW:CPE of 1.2 were recorded maximum seed recovery percent $(0.47), 100$ seed weight $(0.330 \mathrm{~g})$ and seed yield $\left(83.70 \mathrm{~kg} \mathrm{ha}^{-1}\right)$ were recorded with IW:CPE of 1.2 . It was at par with IW:CPE of 1.4. and significantly superior to that of other irrigation levels .But in seed yield plant ${ }^{-1}$ (4.33 g) was maximum recorded with IW:CPE of 1.2 which was significantly superior to that of other irrigation levels.

The results showed that the seed yield attributing parameters as well as seed yield were positively influenced by the nutrient management practices (Table 2). Application of 25\% organic $+75 \%$ inorganic fertilizer was recorded seed recovery percent $(0.46), 100$ seed weight $(0.314 \mathrm{~g})$, seed yield plant ${ }^{-1}$ $(3.96 \mathrm{~g})$ and seed yield $\left(87.34 \mathrm{~kg} \mathrm{ha}^{-1}\right.$. The value of seed recovery percent $(0.46)$ and 100 seed weight $(0.314 \mathrm{~g})$ owing to application of $25 \%$ organic $+75 \%$ inorganic fertilizer was significantly superior to $100 \%$ organic and $100 \%$ inorganic applied plot. But it was statistically at par with the fruit yield due to application of $50 \%$ organic $+50 \%$ inorganic. Whereas seed yield plant ${ }^{-1}(3.96 \mathrm{~g})$ and seed yield $\left(87.34 \mathrm{~kg} \mathrm{ha}^{-1}\right.$ were recorded due to the application of $25 \%$ organic $+75 \%$ inorganic which was significantly superior to that of $100 \%$ organic only, $50 \%$ organic $+50 \%$ inorganic as well as $100 \%$ inorganic fertilizer.

\subsection{Water requirement and water use efficiency}

Water requirement and water use efficiency for different treatments were presented in Table 2. Irrespective nutrient management practices, highest water requirement of $46.82 \mathrm{~cm}$ was observed with IW:CPE of 1.4 where as lowest value of $32.24 \mathrm{~cm}$ was observed with IW:CPE of 0.8 among different irrigation levels. Water requirement irrespective of irrigation levels was highest with $100 \%$ inorganic $(42.43 \mathrm{~cm})$ and lowest under $100 \%$ iorganic $(39.52 \mathrm{~cm})$ among different nutrient management practices. The treatment that received irrigation at IW:CPE of 0.8 registered a highest mean water use efficiency of $533.45 \mathrm{~kg}$ ha- $\mathrm{cm}^{-1}$ and return per $\mathrm{cm}$ water use (₹ $1,549 /$ ), where as lowest value of $373.77 \mathrm{~kg}$ ha- $\mathrm{cm}^{-1}$ and (₹ $1,075 /-$ ) were observed irrigation at IW:CPE of 1.4 Irrespective of

Table 2: Effect of different irrigation levels and nutrient management practices on yield, water requirement, water use efficiency and economics in tomato crop (average mean of 3 years)

\begin{tabular}{|c|c|c|c|c|c|c|c|}
\hline Treatments & $\begin{array}{c}\text { Water } \\
\text { requirement } \\
(\mathrm{cm})\end{array}$ & 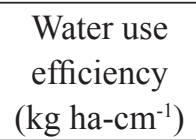 & $\begin{array}{c}\text { Cost of } \\
\text { cultivation } \\
\left(₹ \mathrm{ha}^{-1}\right)\end{array}$ & $\begin{array}{l}\text { Gross } \\
\text { return } \\
\left(₹ \mathrm{ha}^{-1}\right)\end{array}$ & $\begin{array}{c}\text { Net } \\
\text { return } \\
\left(₹ h^{-1}\right)\end{array}$ & $\begin{array}{l}\mathrm{B}: \mathrm{C} \\
\text { ratio }\end{array}$ & $\begin{array}{l}\text { Return cm } \\
\text { water use } \\
\text { (₹ ) }\end{array}$ \\
\hline \multicolumn{8}{|l|}{ Effect of irrigation schedules } \\
\hline IW: $\mathrm{CPE}=0.8$ & 32.24 & 533.45 & 53,260 & $1,03,200$ & 49,940 & 1.93 & 1549 \\
\hline IW: $\mathrm{CPE}=1.0$ & 36.20 & 480.11 & 53,920 & $1,04,280$ & 50,630 & 1.94 & 1398 \\
\hline IW: $\mathrm{CPE}=1.2$ & 41.73 & 442.84 & 54,744 & $1,10,880$ & 56,136 & 2.03 & 1345 \\
\hline IW: $\mathrm{CPE}=1.4$ & 46.82 & 373.77 & 54,640 & $1,05,000$ & 50,360 & 1.92 & 1075 \\
\hline \multicolumn{8}{|l|}{ Effect of nutrient management } \\
\hline $\mathrm{N}_{1}: 100 \%$ organic & 39.52 & 405.11 & 48,880 & 90,060 & 41,260 & 1.75 & 1044 \\
\hline $\mathrm{N}_{2}: 100 \%$ inorganic & 42.43 & 405.60 & 50,560 & $1,03,260$ & 52,700 & 2.04 & 1242 \\
\hline $\mathrm{N}_{3}: 25 \%$ organic $+75 \%$ inorganic & 40.62 & 469.47 & 52,860 & $1,14,420$ & 61,560 & 2.16 & 1301 \\
\hline $\mathrm{N}_{4}: 50 \%$ organic $+50 \%$ inorganic & 40.06 & 455.81 & 53,282 & $1,09,560$ & 56,278 & 2.05 & 1404 \\
\hline
\end{tabular}

Table 3: Coefficients of correlation among yield and yield attributing parameters of tomato

\begin{tabular}{|c|c|c|c|c|c|c|c|c|}
\hline & $\begin{array}{l}\text { Height of } \\
\text { the plant } \\
(\mathrm{cm})\end{array}$ & $\begin{array}{c}\text { Branches } \\
\text { plant }^{-1}\end{array}$ & $\begin{array}{l}\text { Leaves } \\
\text { plant }^{-1}\end{array}$ & $\begin{array}{c}\text { Days to } \\
\text { first harvest } \\
\text { (days) }\end{array}$ & $\begin{array}{l}\text { Fruit reten- } \\
\text { tion plant }{ }^{-1}\end{array}$ & $\begin{array}{l}\text { Mean fruit } \\
\text { weight }(\mathrm{g})\end{array}$ & $\begin{array}{c}\text { Fruit yield } \\
\text { plant }^{-1} \\
(\mathrm{~kg})\end{array}$ & $\begin{array}{c}\text { Mean fruit } \\
\text { yield } \\
\left(\mathrm{t} \mathrm{ha}^{-1}\right)\end{array}$ \\
\hline Height of the plant $(\mathrm{cm})$ & 1.000 & $0.972^{* *}$ & $0.928^{* *}$ & $0.692^{\mathrm{NS}}$ & $0.932^{* *}$ & $0.915^{* *}$ & $0.930^{* *}$ & $0.766^{*}$ \\
\hline Branches plant ${ }^{-1}$ & & 1.000 & $0.881^{* *}$ & $0.783^{*}$ & $0.894^{* *}$ & $0.911^{* *}$ & $0.872^{* *}$ & $0.776^{*}$ \\
\hline Leaves plant ${ }^{-1}$ & & & 1.000 & $0.572^{\mathrm{NS}}$ & $0.963^{* *}$ & $0.963^{* *}$ & $0.990^{* *}$ & $0.774^{*}$ \\
\hline Days to first harvest (days) & & & & 1.000 & $0.576^{\mathrm{NS}}$ & $0.650^{\mathrm{NS}}$ & $0.567^{\mathrm{NS}}$ & $0.461^{\mathrm{NS}}$ \\
\hline Fruit retention plant ${ }^{-1}$ & & & & & 1.000 & $0.942^{* *}$ & $0.985^{* *}$ & $0.762^{*}$ \\
\hline Average fruit weight (g) & & & & & & 1.000 & $0.952^{* *}$ & $0.893^{* *}$ \\
\hline Fruit yield plant ${ }^{-1}(\mathrm{~kg})$ & & & & & & & 1.000 & $0.760^{*}$ \\
\hline Mean fruit yield $\left(\mathrm{t} \mathrm{ha}^{-1}\right)$ & & & & & & & & 1.000 \\
\hline
\end{tabular}

${ }^{* *}$ Correlation is significant at $1 \%$ level; ${ }^{*}$ Correlation is significant at $5 \%$ level; ${ }^{\text {NS }}$ Non-significant correlation 
irrigation levels, highest water use efficiency of $469.47 \mathrm{~kg}$ ha- $\mathrm{cm}^{-1}$ was observed with application of $25 \%$ organic $+75 \%$ inorganic and lowest was with $100 \%$ organic (405.11 kg ha$\mathrm{cm}^{-1}$ ). Whereas, highest return per $\mathrm{cm}$ water use of ₹ $1,044 /-$ was observed with application of $50 \%$ organic $+50 \%$ inorganic and lowest was with $100 \%$ organic (₹ 1,044/-) Similar findings obtained by Chatterjee and Mallick (2008). They reported that IW:CPE of 1.2 irrigation regime produced and more crop water use than IW:CPE of 1.0 and IW:CPE of 0.8 irrigation regimes, respectively.

\subsection{Economics}

Among the irrigation treatments highest gross return, net return and benefit-cost ratio ( $₹ 1,10,880 /-$, ₹ 56,136/- and 2.03) were recorded at $1.2 \mathrm{IW}: \mathrm{CPE}$. The lowest gross and net return was recorded with $0.8 \mathrm{IW}$ :CPE whereas, the lowest benefit-cost ratio was found with 1.4 IW:CPE. The highest gross return, net return and benefit-cost ratio of ₹ $1,14,420 /-$, ₹ $61,560 /$ - and 2.16 respectively were recorded (Table 3 ) with $25 \%$ organic $+75 \%$ inorganic followed by $50 \%$ organic $+50 \%$ inorganic and $100 \%$ inorganic and the lowest value was recorded with $100 \%$ organic (₹ 90,460/-, ₹ 41,260/-, 1.75).

\subsection{Correlation analysis}

The correlation among the yield attributing parameters and fruit yield of tomato were computed using the standard procedure (Gomez and Gomez, 1984) and are presented in Table 3. The positive correlation among yield and yield attributing characters in Table 4 indicate that none of the parameter affect adversely (negatively) to any of the parameters. Further, it is evident from the table that the days to first harvest is not significantly correlated to most of the other parameters. However, the mean fruit yield is significantly correlated to average fruit weight which in turn is highly correlated to other yield attributing characters except days to first harvest. This indicates that the fruit yield per hectare is significantly correlated to all other yield attributing parameters except days to first harvest.

\section{Conclusion}

Application of $25 \% \mathrm{RDF}$ through organic matter along with $75 \%$ of RDF through inorganic fertilizer along with irrigation scheduling at 1.2 IW:CPE can produce significantly higher fruit yield of tomato with highest gross return, net return and $\mathrm{B}: \mathrm{C}$ ratio. The highest mean water use efficiency was observed with irrigation scheduling at $0.8 \mathrm{IW}: \mathrm{CPE}$ and the application of $25 \%$ organic along with $75 \%$ inorganic fertilizer recorded higher water use efficiency.

\section{References}

Arancon, N,Q., Edwards, C.A., Lee, S., Byrne, R., 2006. Effects of humic acids from vermicomposts on plant growth.
European Journal of Soil Biology, 46, 65-69.

Bahadur, A., Singh, J., Singh, K.P., 2004. Response of cabbage to organic manures and biofertilizers. Indian Journal of Horiculture 61(3), 278-279.

Chatterjee, P., Mallik, S., 2008. Dynamics of actual evaporation of tomato under different irrigation regimes and nitrogen levels in new aaluvial zone of West Bengal. Journal of the Indian Society of Soil Science 56(1),49-53

Chatterjee, R., Bandhyopadhyay, S., 2014.Studies on effect of organic, inorganic and biofertilizers on plant nutrient status and availability of major nutrients in tomato. International Journal of Bio-resource and Stress Management 5(1), 093-09

Chaurasia, S.N.S., De, N., Singh, K.P., Kallo, G., 2001. Azotobacter improves the self life of tomato. Indian Journal of Agricultural Science 71(12), 368-371

Gajbhiye, R.P., Sharma, R.R., Tewari, R.N., 2003. Effects of biofertilizers on growth, yield parameters of tomato. Indian Journal. of Horiculture 60(4), 765-767

Gomez, K.A., Gomez, A.A., 1984. Statistical procedures for agricultural research. John Wiley \& Sons Inc.

Gupta, A., Rao, G.G., 1978. The response of spring planted tomato to irrigation and nitrogen. Indian Journal of Agricultural Science 48, 183-184.

Hegde, D.M., Srinivas, K., 1989. Studies on Irrigation and Nitrogen Requirement of Tomato. Indian Journal of Agronomy 34(2), 157-162.

Jack, A.L.H., Rangarajan, A., Culman, S.W., Sooksa, Nguan, T., Thies, J.E., 2011. Choice of organic amendments in tomatotransplants has lasting effects on bacterial rhizosphere communities and crop performance in the field. Applied Soil Ecology 48(1), 94-101.

Kumar, P., Sharma, S.K., 2004. Integrated nutrient management for sustainable cabbage- tomato cropping sequence under mid hill conditions of Himachal Pradesh. Indian Journal of Horticulture 61(4), 331-334.

Kumaran, S., Natarajan, S., Thaburaj, S., 1998. Effect of organic and inorganic fertilizers on growth,yield and quality of tomato. South Indian Horticulture 46(3/4), 203-205

Meheta, B.S., Saini, S.S., 1986. Effect on N,P and K fertilizers on the plant growth ,flowering on yield of tomato cultivar Solangola. Haryana Journal of Horticultural Science 15(1/2), 91-94

Panse, V.G., Sukhatme, P., 1978. Statistical methods for Agricultural workers, ICAR, New Delhi.

Patil, M.B., Mohammed, R.G., Ghadge, P.M., 2004. Effect of organic and inorganic fertilizers on growth,yield and quality of tomato. Journal of Maharashtra Agricultural University 29(2), 124-127 
Premanath., Srivastava, V.K., Dutta, O.P., Swamy, K.R.M., 2008. Vegetable crops Improvement and Production. I $^{\text {st }}$ Edition.PNASF publication, Bangalore, 38.

Senapati, H.K., Dash, A.K., Acharya, R., 2011. Influence of manuring of microbial activity and organic matter decomposition in rice soil. An Asian Journal of Soil Science 6, 69-73
Singh, R., Kholi, U.K., Sharma, S.K., 2000. Effect of nitrogen, phosphorus and potassium combinations on yield of tomato hybrids. Annals of Agriculture Research 21(10), 27-31

Sudhakar, P.S., Purushotham, K., 2008. Studies on the effects of biofertilizers on growth, yield and quality of tomato. The Orissa journal of Horticulturae 36(2), 93-97 